\title{
German Question in 1945-1949: Research of the Problem in Anglo-American Historiography
}

\author{
Kwestie niemieckie w latach 1945-1949: Badanie zagadnienia \\ w historiografii anglo-amerykańskiej
}

\section{- Abstrakt •}

W artykule zidentyfikowano oraz scharakteryzowano dwa główne kierunki angloamerykańskiej nauk historycznych. Szczególną uwagę poświęcono różnym podejściom do problemu repatriacji, warunków wstępnych do stworzenia odrębnego rządu Niemiec Zachodnich, przyczyn i skutków pierwszego kryzysu berlińskiego. W efekcie pozwoliło to na uwidocznienie różnic w politycznej motywacji działań prowadzonych przez wielkie mocarstwa, określenie postaw wobec ich odpowiedzialności za podział państwa, oraz analizę kluczowych etapów rozwoju problematyki niemieckiej w latach 1945-1949.

Słowa kluczowe: kwestia niemiecka, podział Niemiec, problem reparacji, pierwszy kryzys berliński, historiografia angloamerykańska, doktryna powstrzymywania, podejście konserwatywne, kierunek racjonalistyczny, podejście liberalne

\section{- Abstract •}

The article is devoted to the research of the main streams in Anglo-American historiography concerning German problem in 19451949. Two main directions in Anglo-American historical science are identified and characterized. Special attention is paid to the various approaches of historians to the reparation problem, pre-conditions of formation separate West German government, causes and consequences of the first Berlin crisis. In result differences in Great Powers' German politics motives are defined, approaches to estimation of their responsibility for country division are stated, key stages of German question development in the period of 1945-1949 are analyzed.

Keywords: the German question, the zonal division, the reparation problem, the first Berlin crisis, Anglo-American historiography, "containment" school, conservative approach, rationalistic direction, liberal approach 
The German question in 1945-1949 represented a complex problem of determining the forms of the state-political and socio-economic existence of Germany and finding its place in the new system of international relations. The solution of these tasks was planned to be carried out within the framework of the coordinated policy of the four Great Powers - the USSR, the United States, Great Britain and France. However, the inability of the Allies to work out a common course led to the formation of the two German states in 1949. When studying the German question in 1945-1949, British and American researchers follow mainly two directions. Representatives and followers of the "containment" school and rationalistic direction analyze the main stages in German question development using different approaches and methods. There have been revealed no special publications concerning the Anglo-American historiography on the German problem yet. At the same time, the research of different trends in Anglo-American historiography and their comparison with the main provisions of the Soviet historiography on the given problem will contribute to the complex study both of Anglo-American history science since World War II and German problem and its place in international relations during the cold war period.

The "containment" school began to form in Western historiography at the turn of the 1940s-1950s and was based on the ideas of Anglo-American classical geopolitics. The term "containment" in relation to foreign policy of Western countries was proposed by the American diplomat, political scientist and historian George Frost Kennan. In 1946-1947 he theoretically substantiated the famous doctrine of "containment" of the USSR, the usage of which was to prevent the spread of the Soviet influence in Europe. In Anglo-American historiography the "containment" school took shape as an independent direction in the international relations and foreign policy studies in the post-war period. Proceeding from its principles and main provisions the "containment" school may also be characterized as a conservative approach in Anglo-American historiography of the problem.

When analyzing the development of the German problem in 1945-1949 the representatives of this direction proceed from the fact that the defeat of Germany in the Second World War created a vacuum of power in Central Europe. The USSR, because of its geopolitical position, had the opportunity to fill it and establish continental domination. Britain and France were too weakened to form a counterweight to the Soviet power. In such a situation, the US had to assume the functions of deterring communism in Europe, which influenced directly the German policy of the West. Among the followers of the "containment" school are such authors as William Smyser, Stephen Brady, Robert Slusser, Edward Peterson, 
Alexander George, Richard Smoke, Douglas Botting, David Keithley, William Strangand, and Christopher Woodhouse.

Representatives of this direction pay special attention to the analysis of the "Grand designs" of the great powers with respect to post-war Germany. They believe that the German policy of the USSR was originally based on a long-term plan. They relate to the elements of Soviet planning, the gradual strengthening of communist influence in the eastern zone of occupation, the deepening of the economic crisis in Germany, the growth of social tension and the unification of the occupation zones under the power of the left-wing political parties. Thus, the whole of Germany would enter the Soviet sphere of influence without direct intervention of Moscow. One of the main reasons for the disagreement between the USSR and Western countries on the German question was the problem of reparations. Representatives of the "containment" school tend to view Moscow's tough reparation policy as part of a plan to destabilize the socio-economic situation in Germany (Botting, 1985; Slusser, 1985; Woodhouse, 1962). Due to the unconstructive position of the USSR by the end of 1947, negotiations between the four states were at an impasse. The failure of the Moscow and London sessions of the Foreign Ministers Council showed that the further cooperation of the Great Powers on the German question was impossible (George, 1974).

Historians of the "containment" school believe that the Soviet Union sought to use the Berlin blockade in 1948-1949 to expand its sphere of influence in Europe, disrupt the process of economic reconstruction of the western zones and prevent the formation of the West German state. The first Berlin crisis is considered as an element of the strategic plan of the USSR in relation to the whole of Europe and the world as a whole. Analyzing the factor of currency reform in the destabilization of the situation in Berlin, the researchers point to the fact that initially the Western countries sought to take into account the interests of the USSR and did not plan to introduce a new currency in Berlin. However, the appearance of a Soviet new currency in all sectors of the city made the West extend the reform to Berlin. It is assumed that Josef Stalin authorized the introduction of a new currency in Berlin with the aim of economic and political integration of the entire city into the Soviet zone. The success of such a step opened the way to the solution of the German question on the terms of the USSR (Smyser, 1999). The concessions of the West in the Berlin question, according to the authors, were unacceptable, since they would entail the transfer to the Soviet Union of initiative in the formation of the European order (George, 1974). Researchers express confidence that the Western side did not intend to use armed force during the Berlin crisis. However, they emphasize that it was the factor of "nuclear deterrence" that made the 
aggression on the part of the USSR impossible and predetermined the success of the air bridge. The connection between the blockade of Berlin and the subsequent establishment of close allied relations between the USA and the Federal Republic of Germany is particularly emphasized, which is regarded as evidence of the strategic defeat of the USSR (Botting, 1985).

Historians of this trend note that Josef Stalin never aspired to the formation of the separate East German state - GDR, since he initially counted on establishing control over the whole of Germany. The transfer of the eastern territories of the Reich to Poland, as well as the seizure of reparations, significantly weakened East Germany. This testified to the fact that Stalin "thought in terms of a single Germany", in which Moscow could work at realization of a "communist coup" (Slusser, 1985). A. Dulles considered the transfer of part of the German territories to Poland as a well thought-out course of the Soviet side. Subsequently, Josef Stalin could use these territories as a "carrot" in the process of negotiations on the unification of Germany. With a high degree of probability, the Germans could agree to a neutral status and the formation of a government with the predominance of left-wing parties in exchange for the return of territories east of the Oder-Neisse line (Dulles, 1947).

Summing up the basic research principles of "containment" school concerning the German question in zonal period:

- the reparation policy of the USSR, measures for Sovietizing the eastern zone, as well as the blockade of Berlin, are presented in the works of researchers of this direction as stages of Soviet strategic planning for Germany and Europe;

- consistent implementation of Soviet events in the East of Germany forced the West to create a separate West German government. The formation of the GDR was a mechanical response of the Soviet side to the creation of the FRG;

- the moral responsibility for the split of Germany lies on the Soviet side. In this regard, historians do not deny that, given the impossibility of coordinating a quadripartite policy towards Germany, it was the countries of the West that headed for its final division (Brady, 2004; Peterson, 1977). The leading role in the formation of the West German government was played by the British side, which was guided by the tasks of solving economic problems, uniting Europe in front of the threat of communism and preserving the status of Great Britain as a world power (Hughes, 2007; Botting, 1985).

Another group of researchers while studying the development of the German problem in 1945-1949 follow the rationalistic (liberal) direction. British histori- 
ans: Tony Judt, Richard Evans, Mary Fulbrook, David Calleo, Anne Deighton, David Childs, Harold James, Henry Turner, Jeffrey Roberts, and Gareth Pritchard and American researchers: Avril Pittman, Peter Nettle, Philip Mosley, John Gimbel, Wolfram Hanrieder, and Norman Naimark are among them. Representatives of this direction believe that the difference of interests and ideologies of the Great Powers led to the development of a legislative and diplomatic basis for the demarcation of influence spheres in Germany and Europe. That would contribute to preventing a conflict among the Allies. Unlike the followers of geopolitical realism and "containment" school, they believe that initially the Great Powers had no clear plans for post-war Germany. The policy of the Allies in the occupation zones in 1945-1949 was largely based on improvisation and response to the actions of the other side. In such a situation, the split of Germany was the unintended consequence of the cold war, and not the result of the planned policy of the Great Powers. The prospect of unifying the country in such conditions is assessed by the researchers as unrealistic. Neither of the superpowers could create a stable sphere of influence in Europe without the participation of Germany or, at least, its part (Calleo, 1978; Deighton, 2014; Fulbrook, 2000; Gimbel, 1968; Judt, 2005; Naimark, 1996).

Representatives of rationalistic direction differently assess the contribution of the USSR and Western countries to the division of Germany. Most historians note that at the initial stage (1945-1946), the USSR and France showed the greatest intractability in the matter of the German settlement. The main cause of disagreement with the Soviet side was the problem of reparations. Researchers note that the reparation policy of the Soviet Union was due to the difficult situation of the USSR after the war and the urgent need for economic recovery. In the absence of foreign aid, the USSR "could not afford to be magnanimous and generous" (Childs, 1983). From an economic point of view, the reparation policy of the USSR is assessed as successful. It is noted that in the period 1945-1949 short-term economic goals were in the forefront and determined the German policy of the Soviet side. Only since 1949 the Soviet Union began to resolve the long-term political tasks. At the same time, the authors emphasize that the Western countries also could not afford to observe passively the deterioration of the economic situation in Germany. This could destabilize the situation, contribute to the growth of both revanchist ultra-right and ultra-left sentiments. The inability to harmonize economic policy towards Germany as a whole led to the formation of the Bizonia, the development of the Marshall Plan and the currency reform in the western zones. France, which in principle blocked any proposals for the formation of an all-German government and was a "difficult ally" during the negotiations 
of 1945-1946, agreed to the unification of the three occupation zones under US pressure (Naimark, 1996; James, 1989; Pritchard, 2000; Roberts, 2006; Mosely, 1950; Nettl; Judt, 2005; Turner, 1992).

Like the representatives of the "containment" school, the followers of the rationalistic direction note that Britain consistently advocated the formation of a separate West German state and its inclusion in integration structures. The main motive for the actions of the British side was the fears of involving Germany in the sphere of influence of the USSR and the establishment of the Soviet domination on the continent, as well as the potential threat of German militarism and revanchism revival (Deighton, 2014; Judt, 2005; Mosely, 1950; Watt, 1971). In the words of M. Fulbruck, Britain and France in pursuing German politics were obsessed with the "Rapallo complex" (Fulbrook, 2000). Some authors note that the Germans themselves of both eastern and western zones made a significant contribution to the formation of the FRG and the GDR, taking a course of close cooperation with superpowers (Pittman, 1992; Gaddis, 1998; Evans, 1997; Calleo, 1978; Turner, 1992; Fulbrook, 2000).

In the study of the first Berlin crisis, the representatives of rationalistic approach proceed from the fact that the blockade of Berlin was the USSR's response to the policy of the West on the creation of a separate West German state. The actions of the Soviet side are viewed as a pragmatic step taken in response to the decisions of the London conference of the Western powers. The termination of the transport connection between West Berlin and Germany is qualified as a "diplomatic adventure" of Josef Stalin, which was not a part of a well thought-out plan of aggression against Western states (Northedge, 1974; Gimbel, 1968; Judt, 2005).

The representatives of the rationalistic direction express their confidence that the Soviet leader was not going to unleash a war over Berlin, his goal was to prevent the creation of an independent West German state and the resumption of quadripartite negotiations on Germany on terms that were more favorable to the Soviet side. Josef Stalin, guided by the interests of security, sought to create Germany which would be united, neutral and friendly to the USSR (Judt, 2005). Otherwise, as some authors have noted, the USSR could try to force Western troops out of Berlin, but it was virtually impossible taking into account US possession of nuclear weapons (Gaddis, 1989).

The main task of Western countries in Berlin was the minimization of risks and the stabilization of the situation without weakening their own positions in the confrontation with the USSR. The creation of a single neutral Germany, which could become a potential ally of the Soviet Union in the Cold War, was unacceptable. In fact, the authors come to the conclusion that the Western countries 
took a course toward the creation of the FRG and were not interested in resuming the quadripartite negotiations. The actions of the American side during the crisis were experimental, pragmatic and aimed at achieving the economic recovery of Germany and Western Europe (Prowe, 2004). At the same time, representatives of the rationalistic approach point out that the United States, Great Britain and France were interested in preserving the occupation status of Berlin. This gave grounds for a military presence in the western sectors of the city and keeping the German question open. The departure of the American, British and French representatives from the city and the closure of the Berlin question in the conditions of the formation of the West German government could be regarded as consent to the permanent partition of Germany. This jeopardized the entire project for the creation of the FRG and the use of its potential in the interests of the West. For the same reason, the United States, Britain and France subsequently opposed the inclusion of West Berlin in the Federal Republic of Germany, retaining the special status of the city (Turner, 1992).

Summing up the basic research principles of rationalistic direction:

- by the time the Second World War ended, the Great Powers had no clear plans for post-war Germany;

- the development of the cold war led to disagreements in the German policy of the United States and the USSR, which pursued various goals in Germany;

- the reparation policy of the USSR and the blockade of Berlin were the reciprocal steps of the Soviet side to the attempts of the Western countries to form a separate West German government, which was incompatible with the Soviet Union's determination to create a united neutral Germany.

Representatives of both conservative and liberal approaches in Anglo-American historiography paid special attention to the establishment of a "no-return point" in the German settlement, i.e. determination of the moment after which the unification of the occupation zones became totally impossible. The formation of Bizonia in 1946 was traditionally viewed in the Soviet historiography as a violation of the Potsdam agreements, which eventually led to the partition of Germany into two states. Among the representatives of Anglo-American historiography, only $\mathrm{H}$. Turner (rationalistic direction) notes that in many respects, Bizonia became the proto-government of West Germany and made the whole process of negotiations with the Soviet Union much more complicated. Other authors disagree with him and argue that the formation of Bizonia wasn't a conscious step towards the partition of Germany (Judt, 2005; Weir, 1949). For example, J. Gimbel believes that Bizonia was viewed by the United States as an "economic magnet", which would 
"attract" all other zones and, thus, would help to unite Germany. "Magnet theory" concerning German question was proposed by diplomat R. Murphy had many supporters in American administration in the years 1946-1948. From this point of view, the creation of the Bizonia was not a violation of the Potsdam agreements (as it was regarded in the Soviet Union), but just on the contrary - a step towards their successful implementation, though in the indefinite future (Gimbel, 1968).

Most historians of both directions come to the conclusion that the differences in the German policy of the USSR and the Western allies became evident in the spring of 1947 after the failure of the Moscow session of the Foreign Ministers Council. The adoption of the Marshall plan and the USSR's refusal to include East Germany in it predetermined the division of Germany. They pointed out that it finally determined the economic division of Germany, which only had to be confirmed politically. Though representatives of the "containment" school tend to put the main blame for that on the Soviet side, rationalist historians point out that by the spring of 1947 the western Allies themselves weren't interested in German unification and constructive dialogue with the Soviet Union on that problem (James, 1989; Judt, 2005; Gaddis, 1998; George, 1974; Naimark, 1996; Northedge, 1974; Richardson, 1972).

M. Fullbrook, J. Gimbel and W. Hanrieder (all of them represent the rationalistic approach) believe that the course toward the formation of two German states was finally adopted in the summer of 1948 in connection with the currency reform in the western zones and the blockade of Berlin. According to these authors, the first Berlin crisis contributed to the making a final decision to form a separate West German government (Hanrieder, 1967; Fulbrook, 2009).

Despite the different approaches in interpreting the reasons for the split in Germany and the motives for the actions of the great powers in 1945-1949, representatives of the two directions come to the common conclusion that the division of Germany was convenient and beneficial for all Great Powers, as well as for the Germans themselves. The creation of the Federal Republic of Germany and the German Democratic Republic made it possible to demarcate the spheres of influence between the superpowers in Europe and to remove the potential threat of the revival of the German revanchism. This helped to stabilize the international order and minimize the risk of armed conflict in Europe (Calleo, 1978; Gaddis, 1989, 1998; Hanrieder, 1967; Judt, 2005; Prowe, 2004).

In the process of studying the German question and the policy of the Great Powers towards Germany in 1945-1949, researchers in the United Kingdom and the United States use two main approaches. The followers of "containment" school (conservative approach) believe that the Great Powers used the defeat and occu- 
pation of Germany in their long-term strategic goals, having developed "Grand designs" to form their spheres of influence. The existence of plans for a German settlement correspond to the interest of the Great Powers in prevention of international anarchy. From this point of view, the main responsibility for the division of Germany lies with the Soviet Union, which, through its rigidity and intractability pushed the countries of the West to go for the creation of the separate West German state. The Soviet occupation policy, position on reparations and eastern border questions, Berlin blockade - all these actions are estimated as the elements of the strategic plan aimed at destabilization of Germany as a whole and its inclusion into the Soviet sphere of influence.

Representatives of the rationalistic direction (liberal approach) tend to deny the existence of strategic plans concerning post-war Germany both in the West and in the East. They analyze the policy of the Allies in occupied Germany taking into account the internal problems and objective needs of the victorious powers, as well as changes in the situation in Germany itself and in the international relations. The majority of them believe that it was three western Allies which took the course to the formation of a separate West German state. By the spring of 1947 they hadn't been interested in constructive negotiations on German unity with the Soviets. The authors come to the conclusion that Great Britain, guided by a complex of national interests, became the most active supporter of the creation of the separate West German government.

Reflecting on the "no-return points" in German settlement in this period historians of both directions refer mainly to the failure of the Moscow session of the Foreign Ministers Council in 1947 and the adoption of the Marshall plan, as well as the Berlin blockade of 1948-1949. They tend to appraise these events as key points that ultimately determined the formation of the two German governments in 1949 .

\section{References:}

Botting, D. (1985). From the Ruins of the Reich. Germany 1945-1949. New York: Crown Publishers.

Brady, S. (2004). The U.S. Congress and the German-American Relations. In: The United States and Germany in the Ers of the Cold War, 1945-1990. Washington: German Historical Institute.

Calleo, D. (1978). The German Problem Reconsidered. Cambridge: Cambridge University Press.

Childs, D. (1983). The GDR: Moscow's German Ally. London: Allen \& Unwinn. 
Deighton, A. (2014). Germany and East-Central Europe, 1945-1990: The View from London. In: Imposing, Maintaining and Tearing Open the Iron Curtain. The Cold War and East-Central Europe, 1945-1989 (p. 213). New York: Lexington.

Dulles, A. (1947). Alternatives for Germany. Foreign Affairs, 25, 3, 421-432.

Evans, R. (1997). Rereading German History: From Unification to Reunification, 18001996. London-New York: Routledge.

Fulbrook, M. (2000). Interpretations of the Two Germanies, 1945-1990. London: Macmillan.

Fulbrook, M. (2009). A History of Germany, 1918-2008. The Divided Nation. Oxford: Walley-Blackwell.

Gaddis, J.L. (1989). The Long Peace. Inquiries into the History of Cold War. New York; Oxford: Oxford University Press.

Gaddis, J.L. (1998). We Know Now. Rethinking Cold War History. Oxford: Oxford University Press.

George, A.S. (1974). Deterrence in American Foreign Policy. New York: Columbia University Press.

Gimbel, J. (1968). The American Occupation of Germany. Politics and the Military, 1945-1949. Stanford: Stanford University Press.

Hanrieder, W. (1967). West German Foreign Policy, 1949-1963. International Pressure and Domestic Response. Stanford: Stanford University Press.

Hughes, G. (2007). Britain, Germany and the Cold War. The Search for European Detente, 1949-1967. London; New York: Routledge.

James, H. (1989). German Identity. New York: Routledge.

Judt, T. (2005). Postwar. A History of Europe Since 1945. New York: Penguin Press.

Mosely, P. (1950). The Occupation of Germany. New Light on How the Zones Were Drawn. Foreign Affairs, 28, 4, 580-604.

Naimark, N. (1996). The Russians in Germany. The History of the Soviet Zone of Occupation, 1945-1949. Cambridge (Mass.): Harvard University Press.

Nettl, P. (1951). German Reparations in the Soviet Zone. Foreign Affairs, 29, 2, 300-307.

Northedge, F.G. (1974). A Hundred Years of International Relations. London: Duckworth.

Peterson, E. (1977). The American Occupation of Germany: Retreat to Victory. Detroit: Wayne State University.

Pittman, A. (1992). From Ostpolitik to Reunification: West German-Soviet Political Relations Since 1974. New York: Cambridge University Press.

Pritchard, G. (2000). The Making of the GDR. From Antifascism to Stalinism. Manchester: Manchester University.

Prowe, D. (2004). Berlin. Catalyst and Fault Line of the German-American Relations in the Cold War. In: The United States and Germany in the Era of the Cold War, 19451990 (pp. 165-171). Washington: German Historical Institute.

Richardson, J. (1972). Cold-War Revisionism. World Politics, 24, 4, 579-612.

Roberts, G. (2006). Stalin's Wars. From World War to Cold War, 1939-1953. New Haven and London: Yale University Press.

Slusser, R. (1985). The Impact of World War II on the Soviet Union. In: S. Linz (ed.), Soviet Policy and the Division of Germany, 1941-1945. Irvine: Rowman \& Allanheld. 
Smyser, W. (1999). From Yalta to Berlin: The Cold War Struggle Over Germany. New York: St. Martin's Griffin.

Turner, H. (1992). Germany from Partition to Unification. New Haven and London: Yale University Press.

Watt, D. (1971). Anglo-German Relations Today and Tomorrow. In: Britain and West Germany (pp. 204-218). London: Oxford University Press.

Weir, C. (1949). Economic Developments in Western Germany. International Affairs, 25, 3, 249-256.

Woodhouse, C. (1962). British Foreign Policy Since the Second World War. New York: Praeger. 